\title{
PELATIHAN PENERAPAN AKUNTANSI PERUSAHAAN DAGANG SMA TRI RATNA
}

\author{
Liana Susanto ${ }^{1}$, Merry Susanti² \\ ${ }^{I}$ Jurusan Akuntansi, Universitas Tarumanagara \\ Email: lianas@fe.untar.ac.id \\ ${ }^{2}$ Jurusan Akuntansi, Universitas Tarumanagara \\ Email:merrys@fe.untar.ac.id
}

\begin{abstract}
ABSTRAK
Kegiatan pengabdian kepada masyarakat kali ini dilakukan di SMA Tri Ratna yang beralamat di Jalan Talib No 35-37 RT 9 RW2, Krukut, Tamansari, Jakarta Barat. Tujuan dari kegiatan ini adalah untuk memberikan pelatihan kepada siswa/i SMA Tri Ratna agar mereka dapat memahami, membuat jurnal transaksi dan jurnal penyesuaian serta menyusun laporan keuangan untuk perusahaan dagang yang terdiri dari laporan laba/ rugi, laporan perubahan modal dan laporan posisi keuangan. Sebelum kami melakukan pelatihan, dilakukan survey terlebih dahulu untuk mengetahui topik apa yang perlu kami berikan serta jumlah siswa yang akan mengikuti pelatihan ini. Tahap selanjutnya adalah menyiapkan dan memperbanyak modul pelatihan serta mencari jadwal pelatihan. Pada hari pelatihan, para dosen memberikan penjelasan serta contoh soal kepada para siswa/i untuk memahami, membuat jurnal transaksi dan jurnal penyesuaian serta menyusun laporan keuangan untuk perusahaan dagang. Tahapan akhir adalah para siswa/i diberikan kuis untuk mengetahui apakah mereka dapat memahami penjelasan yang telah diberikan sebelumnya. Setelah hasil kuis dinilai, dapat disimpulkan bahwa sebagian besar dari mereka dapat mengerjakan soal yang diberikan dengan benar dan ini menunjukkan bahwa materi pelatihan akuntansi perusahaan dagang sudah dapat dipahami dengan baik. Selain itu, siswa/i juga diminta untuk mengisi kuesioner untuk mengetahui apakah pelatihan akuntansi perusahaan dagang ini memberikan manfaat kepada para siswa dan topik apakah yang mereka minati untuk pelatihan selanjutnya. Harapan kami adalah pelatihan akuntansi keuangan yang telah diberikan dapat bermanfaat bagi para siswa/i. Selesainya kegiatan pelatihan ini ditutup dengan memberikan kenang-kenangan kepada para siswa.
\end{abstract}

Kata kunci: akuntansi perusahaan dagang, SMA Tri Ratna

\section{PENDAHULUAN}

Menurut Weygandt et al. (2015), laporan laba rugi merupakan salah satu laporan keuangan. Laporan Laba Rugi mewakili pendapatan dan beban serta menghasilkan laba bersih atau rugi bersih selama periode waktu tertentu. Pemilik perusahaan dan investor umumnya mengetahui kinerja perusahaan dari laporan keuangan perusahaan tersebut. Kegiatan perekonomian di Indonesia semakin berkembang yang ditandai dengan bertambahnya jumlah UKM menengah yang semakin bermunculan. Jenis perusahaan yang cukup banyak adalah perusahaan dagang. Siklus perusahaan dagang cenderung sederhana, dimulai dengan membeli persediaan kemudian menjual kembali persediaan tersebut untuk memperoleh laba bagi perusahaan tersebut.

Setiap perusahaan umumnya membutuhkan tenaga akuntansi dalam mencatat transaksi perusahaannya, yang nantinya akan digunakan untuk penyusunan laporan keuangan. Meskipun perusahaan dagang yang ada sekarang ini masih dalam ukuran kecil, semakin lama akan semakin berkembang sehingga menjadi perusahaan besar. Permintaan tenaga akuntansi akan semakin meningkat. Peluang bekerja di bidang akuntansi semakin terbuka lebar. Dikarenakan bertambah banyaknya perusahaan dagang yang bermunculan, maka diperlukan pelatihan mengenai akuntansi perusahaan dagang.

Kami melakukan pengabdian kepada masyarakat di SMA Tri Ratna karena berdasarkan survey pendahuluan para siswa/i belum diajarkan secara mendalam mengenai akuntansi perusahaan 
dagang. Untuk itu, mereka perlu dibekali ilmu akuntansi perusahaan dagang yangakan berguna bagi mereka saat melanjutkan ke jenjang pendidikan yang lebih tinggi ataupun dalam bekerja.

\section{METODE PELAKSANAAN PKM}

Metode pelaksanaan yang digunakan adalah:

1. Menjelaskan terlebih dahulu teori yang terkait dengan kegiatan perusahaan dagang,

2. Menjelaskan mengenai akuntansi perusahaan dagang (menjelaskan jurnal mengenai perusahaan kemudian secara step by step menjelaskan penyusunan laporan keuangan).

3. Memberikan kuis untuk mengetahui sejauh mana pemahaman mereka mengenai akuntansi perusahaan dagang.

\section{AKUNTANSI PERUSAHAAN DAGANG}

Menurut Horngren dan Harrison (2007), operasi perusahaan dagang terdiri dari membeli dan menjual produk dan bukan jasa. Menurut Dewi, Sugiarto, dan Susanti (2017), kegiatan dari perusahaan dagang tidak sama dengan kegiatan perusahaan jasa. Kegiatan utama dari perusahaan jasa adalah memberikan jasa kepada pengguna jasa, sedangkan kegiatan utama dari perusahaan dagang adalah membeli barang dan kemudian menjualnya kembali tanpa merubah bentuk dasarnya atau menambah manfaat dari barang tersebut. Menurut Weygandt, Kimmel, dan Kieso (2013) sumber utama pendapatan bagi perusahaan dagang adalah berasal dari penjualan barang dagang. Dalam beban perusahaan terdapat Harga Pokok Penjualan (HPP) yaitu biaya dari barang dagang yang terjual selama satu periode waktu.

Siklus operasi perusahaan dagang berbeda dengan perusahaan jasa dan biasanya lebih panjang dibandingkan perusahaan jasa karena terdapat proses pembelian dan penjualan barang dagang. Perusahaan dagang memiliki satu perkiraan aset tambahan yaitu persediaan barang dagang.

Perusahaan harus memiliki catatan mengenai persediaan barang dagang yang tersedia untuk dijual dan yang telah terjual. Perusahaan dapat memilih salah satu dari dua sistem pencatatan yaitu:

1. Sistem persediaan perpetual adalah suatu sistem pencatatan dimana terdapat catatan rinci mengenai biaya dari setiap persediaan barang dagang yang dibeli dan dijual. Harga Pokok Penjualan dicatat setiap saat terjadinya penjualan.

2. Sistem persediaan periodik adalah suatu sistem pencatatan dimana catatan mengenai persediaan tidak dibuat sepanjang suatu periode. Harga Pokok Penjualan ditentukan pada akhir periode akuntansi.

\section{JURNAL AKUNTANSI PERUSAHAAN DAGANG}

Berikut disajikan jurnal umum perusahaan dagang dengan sistem pencatatan persediaan perpetual dapat dilihat pada Tabel 1 .

Tabel 1. Jurnal Umum Perusahaan Dagang dengan Sistem Pencatatan Persediaan Perpetual

\begin{tabular}{clcc}
\hline No & \multicolumn{1}{c}{ Account tittles } & D & $\mathrm{K}$ \\
\hline 1 & $\begin{array}{l}\text { Mencatat transaksi pembelian secara tunai: } \\
\text { Persediaan barang dagang } \\
\text { Kas }\end{array}$ & $\mathrm{xxx}$ & $\mathrm{x}$ \\
\hline 2 & $\begin{array}{l}\text { Mencatat transaksi pembelian secara kredit: } \\
\text { Persediaan barang dagang } \\
\text { Hutang dagang }\end{array}$ & $\mathrm{xxx}$ & \\
& & & $\mathrm{x}$ \\
\hline
\end{tabular}




\begin{tabular}{|c|c|c|c|}
\hline 3 & $\begin{array}{l}\text { Mencatat transaksi retur pembelian secara tunai: } \\
\text { Kas } \\
\quad \text { Persediaan barang dagang }\end{array}$ & $\mathrm{XXX}$ & $\mathrm{x}$ \\
\hline 4 & $\begin{array}{l}\text { Mencatat transaksi retur pembelian secara kredit: } \\
\text { Hutang dagang } \\
\text { Persediaan barang dagang }\end{array}$ & XXX & $\mathrm{X}$ \\
\hline 5 & $\begin{array}{l}\text { Mencatat transaksi pembayaran ongkos angkut: } \\
\text { Persediaan barang dagang } \\
\text { Kas }\end{array}$ & XXX & $\mathrm{X}$ \\
\hline 6 & $\begin{array}{l}\text { Mencatat transaksi pelunasan hutang dalam periode } \\
\text { diskon: Hutang } \\
\text { dagang }\end{array}$ & $\mathrm{XXX}$ & \\
\hline 7 & $\begin{array}{l}\text { Mencatat transaksi pelunasan hutang lewat periode } \\
\text { diskon: Hutang } \\
\text { dagang }\end{array}$ & $\mathrm{XXX}$ & \\
\hline 8 & $\begin{array}{l}\text { Mencatat transaksi penjualan secara tunai: } \\
\text { Kas } \\
\quad \text { Penjualan }\end{array}$ & XXX & $\mathrm{x}$ \\
\hline 9 & $\begin{array}{l}\text { Mencatat transaksi penjualan secara kredit: } \\
\text { Piutang dagang } \\
\quad \text { Penjualan }\end{array}$ & XXX & $\mathrm{X}$ \\
\hline 10 & $\begin{array}{l}\text { Mencatat transaksi retur penjualan secara tunai: } \\
\text { Retur penjualan } \\
\text { Kas }\end{array}$ & $\mathrm{XXX}$ & $\mathrm{X}$ \\
\hline 11 & $\begin{array}{l}\text { Mencatat transaksi retur penjualan secara kredit: } \\
\text { Retur penjualan } \\
\quad \text { Piutang dagang }\end{array}$ & XXX & $\mathrm{X}$ \\
\hline 12 & $\begin{array}{l}\text { Mencatat transaksi Pembayaran ongkos angkut: } \\
\text { Ongkos angkut } \\
\text { Kas }\end{array}$ & $\mathrm{XXX}$ & $\mathrm{X}$ \\
\hline 13 & $\begin{array}{l}\text { Mencatat transaksi penerimaan piutang dalam periode } \\
\text { diskon: } \\
\text { Kas }\end{array}$ & $\mathrm{XXX}$ & \\
\hline 14 & $\begin{array}{l}\text { Mencatat transaksi penerimaan piutang lewat periode } \\
\text { diskon: } \\
\text { Kas }\end{array}$ & XXX & \\
\hline
\end{tabular}




\section{LAPORAN KEUANGAN PERUSAHAAN DAGANG}

Laporan keuangan perusahaan dagang dapat dilihat pada Gambar 1 dan Gambar 2.

\begin{tabular}{|c|c|}
\hline & $\begin{array}{l}\text { Laporan Laba Rugi } \\
\text { PD ABC } \\
\text { ntuk periode yang berakhir } 31 \text { Maret } 2018\end{array}$ \\
\hline Penjualan & $\mathrm{xxx}$ \\
\hline HPP & $(\mathrm{xxx})$ \\
\hline Laba kotor & $\overline{\mathrm{xxx}}$ \\
\hline Beban operasi: & \\
\hline Beban sewa & $\mathrm{xxx}$ \\
\hline Beban utilitas & $\mathrm{xxx}$ \\
\hline Beban gaji & $\underline{\mathrm{xxx}}$ \\
\hline Total beban operasi & $(\mathrm{xxx})$ \\
\hline Laba bersih & $\mathrm{xxx}$ \\
\hline
\end{tabular}

Gambar 1. Laporan Laba Rugi

\begin{tabular}{|c|c|}
\hline \multicolumn{2}{|c|}{$\begin{array}{c}\text { Laporan Perubahan Ekuitas } \\
\text { PD ABC } \\
\text { Untuk periode yang berakhir } 31 \text { Maret } 2018\end{array}$} \\
\hline Modal awal & $\mathrm{xxx}$ \\
\hline Laba bersih & $\mathrm{xxx}$ \\
\hline Modal akhir & $\mathrm{xxx}$ \\
\hline \multicolumn{2}{|r|}{$\begin{array}{c}\text { Laporan Posisi Keuangan } \\
\text { PD ABC } \\
\text { Per 31 Maret } 2018 \\
\end{array}$} \\
\hline Aset: & \\
\hline Kas & $\mathrm{xxx}$ \\
\hline Piutang dagang & $\mathrm{xxx}$ \\
\hline Persediaan barang & $\underline{\mathrm{xxx}}$ \\
\hline Total Aset & $\overline{x x x}$ \\
\hline \multirow{2}{*}{\multicolumn{2}{|c|}{$\begin{array}{l}\text { Kewajiban dan ekuitas } \\
\text { Kewaiiban. }\end{array}$}} \\
\hline & \\
\hline Hutang dagang & $\mathrm{xxx}$ \\
\hline Hutang gaji & $\underline{\mathrm{xxx}}$ \\
\hline Total kewajiban & $\mathrm{xxx}$ \\
\hline \multicolumn{2}{|l|}{ Modal: } \\
\hline Modal, Anton & $\underline{\mathrm{xxx}}$ \\
\hline Total kewajiban dan modal & $\overline{\mathrm{xxx}}$ \\
\hline
\end{tabular}

Gambar 2. Laporan Posisi Keuangan 


\section{HASIL DAN PEMBAHASAN}

Target dari diadakannya pelatihan ini adalah agar para siswa/i dapat memahami secara mendalam mengenai akuntansi perusahaan dagang. Agar dapat mengetahui apakah target dapat tercapai, maka di pertemuan terakhir kami memberikan kuis kepada para siswa/i. Sebelum diberikan kuis, pada pertemuan sebelumnya kami memberikan pelatihan kepada para siswa/i dengan cara menjelaskan teori serta memberikan contoh-contoh soal terkait dengan akuntansi perusahaan dagang. Dalam pelatihan ini siswa diberikan kesempatan untuk bertanya bila ada halhal yang kurang dimengerti. Dalam sesi pertemuan ini para siswa/i cukup aktif bertanya dan menjawab pertanyaan yang kami berikan.

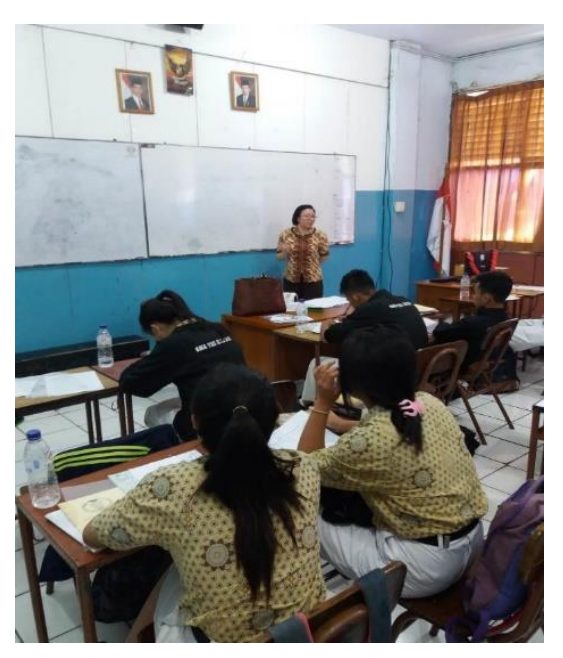

Gambar 3. Sesi Pertemuan

Pada pertemuan selanjutnya kami memberikan soal mengenai akuntansi perusahaan dagang. Para siswa/siswi diberikan waktu untuk menyelesaikan soal tersebut. Setelah waktu selesai, para siswa diminta untuk mengumpulkan hasil jawaban mereka untuk diperiksa dan diberi nilai. Setelah jawaban kuis dikumpulkan, soal kuis tersebut dibahas bersama-sama dengan para siswa agar para siswa mengetahui jawaban kuis yang benar. Hasil pemeriksaaan terhadap kuis menunjukkan bahwa target pelatihan telah tercapai, yang terlihat dari hasil kuis berkisar dari nilai 80-100. Dengan demikian,dapat dikatakan bahwa target dari pelatihan ini telah tercapai.

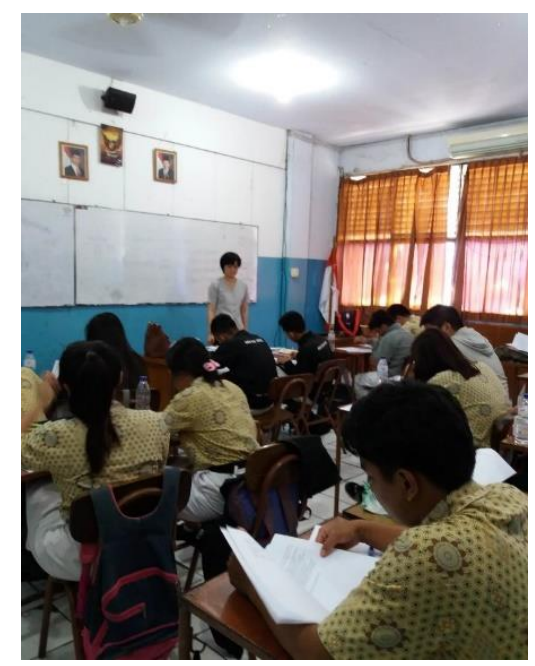

Gambar 4. Sesi Pemberian Soal 


\section{Ucapan Terima Kasih}

Kami mengucapkan terima kasih kepada semua pihak yang telah mendukung terlaksananya kegiatan pelatihan yang kami lakukan, yaitu: Rektor Universitas Tarumanagara, Direktur Penelitian dan Pengabdian Kepada Masyarakat Universitas Tarumanagara, Dekan dan segenap pimpinan Fakultas Ekonomi Universitas Tarumanagara, para guru serta siswa/i SMA Tri Ratna, serta semua pihak yang tidak dapat kami sebutkan satu per satu.

\section{REFERENSI}

Dewi, Sofia Prima, Elizabeth Sugiarto D, dan Merry Susanti. (2017). Pengantar Akuntansi.

Sekilas Pandang Perbandingan dengan SAK yang Mengadopsi IFRS, SAK ETAP, dan SAK EMKM. Bogor: In Media

Ikatan Akuntan Indonesia. (2013). Standar akuntansi keuangan per 1 Juni 2012. Edisi Revisi. Cetakan Kedua. Jakarta: Ikatan Akuntan Indonesia

Weygandt, Jerry J., Paul D. Kimmel, dan Donald E. Kieso. (2013). Financial Accounting. IFRS Edition. $2^{\text {nd }}$ Edition. NJ: John Wiley \& Sons 